O.M. Nikipelova, Dr. of Chemistry,

A.Yu. Kisilevskaya, $\mathrm{PhD}$,

L.B. Solodova,

The Ukrainian Research Institute of Medical Rehabilitation and Balneology of Ministry of Health of

Ukraine, Odessa

\title{
DEVELOPMENT OF METHOD FOR THE MINERAL WATER CATALASE ACTIVITY DETERMINATION
}

Introduction. The availability in Ukraine of diversified unique natural mineral water (MW) resources does necessitate a detailed study of that water properties in order of its widespread use in the balneological and extra-resort practice, considering the MW as an important factor of population health preserving and improving [1]. The mineral water rational use is largely determined by its physical and chemical composition, sanitary and microbiological status, the presence of autochthonous microorganisms and those microorganisms' ability to influence the water organoleptic characteristics and biological properties. In MW practical use the key importance is tribute to controlling the water quality parameters for the prediction of water safety degree and the detection of biological exposure.

The MW biological effect depends on the mineralization degree, chemical composition, presence of biologically active components and compounds, as well as on their microbial cenosis' metabolic products. Analyzing the mineral water microorganisms' list we reveal their active biochemical effect [1].

The numerous microorganisms contributing to the mineral water's autochthonous microflora do often include significant concentrations in saprophytic microorganisms producing the catalase as an enzyme of oxidoreductases class, a heme-containing chromoproteid making part of the cell's antioxidant system and acting as an antiperoxidant protector agent [2]. Peroxide mechanisms may occur in the brain and in other tissues during aging, when exposure to poisons and toxins, when cerebral apoplexy, at nervous system injuries, and others processes. The biological role of catalase refers to the complex enzymatic protection of cell membranes against hydrogen peroxide-caused degradation. The catalase does metabolize the hydrogen peroxide, preventing its accumulation in the cell through producing water and oxygen. The most relevant catalase application relates to the treatment of diseases requiring an effective antioxidant protector: cardiovascular, rheumatic diseases, allergies, central and autonomic nervous systems' diseases, gastrointestinal diseases, oncology, plastic surgery, etc. [2].

Given the important physiological role of catalase, it is necessary to determine the mineral water's enzymatic activity. At present the methodology for MW enzymatic activity determination is still absent, so such methods' elaboration problem is top priority one.

Analysis of recent researches and publications. Methods for catalase activity quantitative determination are based on the estimation of enzyme-cleaved hydrogen peroxide quantity when enzymatic activity is assessed by the catalase index.

The reference sources describe several methods of catalase activity assessment, but these methods relate to the biological objects (plasma, serum, etc.). To develop methods for determining the MW catalase activity we proceed to review the available approaches.

Known is the enzymatic activity determining method by Bach and Oparin based onto titration [3], through assessing the quantity of hydrogen peroxide decomposed during incubation with the enzyme. The amount of hydrogen peroxide in the reaction mixture is assessed by titration with a Potassium permanganate solution in an acidic environment. However, this method has such drawbacks as a high labour intensity, results' poor reproducibility and low sensitivity. 
Another known approach to catalase activity determining is Warburg's gasometric method and its modifications. This methodology essence relates to capturing and measuring the volume of oxygen liberated after introducing the catalase extract into aqueous solution of hydrogen peroxide [4]. This method's disadvantages refer to the need for calculating and taking into account the vessel's constant volume, the dependence on external conditions (temperature, sea level altitude and atmospheric pressure) and the need in appliance for mechanical shaking device.

There exists also a fluorimetric catalase activity assessment method with further modifications determining the blood serum enzymatic index $[5,6]$. Despite the method's high sensitivity, it is very expensive due to the use of a microtabet reader for increasing the sensitivity.

Another highly sensitive but expensive methodology departs from assessing the catalase activity on the base of the Clark oxygen electrode application, and this method modification [7] using the LabVIEW virtual tools.

There exist some polarographic methods, for example, [8], but they require special equipment and laboratory space arrangement.

The potentiometric method is based on measuring the rate of fluoride ions release using the fluorine-selective electrode as a result of 4-fluorophenol enzymatic cleavage with peroxidase in the presence of hydrogen peroxide [9]. In such a way it becomes possible to determine the amount of aerobic (catalase-positive) microorganisms. Still this method requires working out all the parameters for every studied object.

In biomedicine and food industry known is the electrochemical method of catalase-positive microorganisms' detection and identification, developed on the EIA and amperometry basis for highsensitivity enzymes detection [10]. This method uses nitrocellulose membranes as a solid phase for bacteria selective capturing with those microorganisms' antibodies. This is a technologically new approach, of high sensitivity, but the method is also expensive because of the costly equipment use.

Thus, the above spoken catalase assay methods are not available for certain objects' analysis facilities and can never be applied to mineral water analysis.

The Aim of the Research consists in developing a method for the mineral water catalase activity determination with sufficient accuracy and precision, and refers introducing a new parameter to assess the MW quality and biological value.

Main Body. At present, one of the basic analytical methods used at wide range of chemical, clinical, biological etc., laboratories is the spectrophotometry.

As the methodical prototype for catalase activity assessing accepted is Korolyuk's method [11] representing a modification of the biological objects' catalase activity spectrophotometric evaluation; the principle departs from the hydrogen peroxide's ability to interact with molybdenum salts forming a stable coloured complex. The method is based on the titration in an acidic environment with Potassium permanganate of hydrogen peroxide remaining after the catalase action,

$$
5 \mathrm{H}_{2} \mathrm{O}_{2}+2 \mathrm{KMnO}_{4}+4 \mathrm{H}_{2} \mathrm{SO}_{4} \rightarrow 2 \mathrm{KHSO}_{4}+2 \mathrm{MnSO}_{4}+8 \mathrm{H}_{2} \mathrm{O}+5 \mathrm{O}_{2} \text {. }
$$

The catalase activity is determined with the amounts of cleaved hydrogen peroxide $(\mathrm{mg})$

$$
C=(B-A) \times Q \text {, }
$$

where $C$ - catalase activity, mg;

$(B-A)$ - difference between results of titrating the control and test samples with $0,1 \mathrm{n}$-solution of Potassium permanganate, $\mathrm{cm}^{3}$;

$Q$ - amount of hydrogen peroxide ( $85 \mathrm{mg}$ ), corresponding to $1 \mathrm{~cm}^{3}$ of $0,1 \mathrm{n}$-solution of Potassium permanganate.

Reagents: $4 \%$ ammonium molybdate solution and $0,03 \%$ hydrogen peroxide solution.

This research object was to improve the method for determining the catalase activity by spectrophotometric method of registering the coloured product of reaction when hydrogen peroxide not decomposed after incubation with catalase interacts with ammonium molybdate; the ultimate goal being to elaborate this method application to various types of mineral water. 
Results. The formulated problem is solved using for spectrophoto-

Table 1 metric MW catalase activity estimation the mineral water research sample

Finding the mineral water incubation time

\begin{tabular}{c|c}
\hline $\begin{array}{c}\text { Incubation } \\
\text { time, min }\end{array}$ & $\begin{array}{c}\text { Catalase } \\
\text { activity, } \%\end{array}$ \\
\hline 0 & 45,17 \\
\hline 5 & 46,13 \\
\hline 10 & 45,75 \\
\hline 15 & 47,68 \\
\hline 20 & 49,81 \\
\hline 25 & 50,19 \\
\hline 30 & 50,58 \\
\hline 35 & 49,81 \\
\hline 40 & 49,42 \\
\hline
\end{tabular}
volume of 5,0 ml, assigning its incubation time as $30 \mathrm{~min}$; the catalase activity is calculated as a percentage.

$$
A_{\text {cat }}=\frac{A_{\text {control }}-A_{\text {test }}}{A_{\text {control }}} \times 100 \%,
$$

where $A_{\text {cat }}$ - catalase activity, $\%$;

$A_{\text {control }}$ - the control (blank) sample optic density;

$A_{\text {test }}$ - the tested sample optic density.

The method essential feature is that the test MW sample volume increased from 0,1 to $5,0 \mathrm{ml}$, with simultaneous increase of incubation time from 10 to $30 \mathrm{~min}$. Comparing to the prototype model we did change the formula of enzymatic activity calculation, having excluded the incubation time which has the same value. The test MW sample of $5 \mathrm{~cm}^{3}$ is added with $2 \mathrm{~cm}^{3} 0,03 \%$ of hydrogen peroxide water solution. The blank sample contains instead of mineral one, $5 \mathrm{~cm}^{3}$ of distilled water. Both samples are incubated during 30 minutes at $37^{\circ} \mathrm{C}$. To

Table 2 stop the reaction, $1 \mathrm{~cm}^{3}$ of $4 \%$ ammonium molybdate water solution is introduced. Both blank and test samples' colour intensity is measured with JEN WAY spectrophotometer; wavelength $-410 \mathrm{~nm}$, cuvette $-10 \mathrm{~mm}$. The MW catalase activity determination results, $A_{\text {cat }}, \%$, are processed following the formula (1).

Considering low index of MW catalase activity, estimated is the optimal delay of mineral water incubation (Table 1).

Table 1 does clearly represent that first 30 minutes of incubation running the MW catalase activity augments and further time increasing we observe its drop. Therefore the selected incubation time was 30 minutes.

The results of MW catalase activity measurement are shown at Table 2. Calculated are: the mean value, the root-mean square deviation $S$ and the relative error $S_{r}$.

The standard relative error values $\left(S_{r}\right)$ are 1,$58 ; 1,03 ; 0,29$ and $0,33 \%$ respectively that make significantly below the bound error assigned for spectrophotometric analyses and the given optic density range.

Conclusions. After working out the method for catalase activity determining for various types mineral water, further the catalase activity index may be used as an additional criterion for evaluating the mineral water quality and biological activity. The elaborated method has been adopted for issuing a respective patent from the State Intellectual Property Office. 


\section{Література}

1. Николенко, С.И. Аутохтонная микрофлора питьевых минеральных вод // В кн. “Маломинерализованные хлоридные натриевые воды Украины”. - Одесса, 2002. - С. 59 - 68.

2. Терапевтически активные метаболиты микрофлоры минеральных вод / С.И. Николенко, Н.Г. Славина, К.Б. Зайцева, С.Н. Глуховская // Вода и здоровье - 2001: сб. науч. ст. - Одесса, 2001. - С. $159-162$.

3. Сериков, Ю.А. Титриметрический метод определения хлорат-иона в природных водах / Ю.А. Сериков, Н.В. Серкова // Заводская лаборатория. Диагностика материалов. — 2010. Т. 76, № 10 . - С. $21-24$.

4. Биоиндикация и биотестирование - методы познания экологического состояния окружающей среды / Т.Я. Ашихмина [и др.]. - Вып. 4, Ч. 3. - Киров: ВятГГУ, 2005. - 51 с.

5. Fluorimetry as a Simple and Sensitive Method for Determination of Catalase Activity / S. Naazeri, M. Rostamian, B. Yaghmaei, M. Hedayati // Zahedan Journal of Research in Medical Sciences. 2014. - Vol. 16, No. 2. - PP. 64-67.

6. $\mathrm{Wu}, \mathrm{M}$. Determination of the activity of catalase using a europium(III)-tetracycline-derived fluorescent substrate / M. Wu, Z. Lin, O.S. Wolfbeis // Analytical Biochemistry. — 2003. — Vol. 320, Issue 1. PP. $129-135$.

7. Sandeep Kumar Jha. An ultra sensitive method for rapid in vitro catalase assay with software based approach using LabVIEW virtual instrumentation / Sandeep Kumar Jha, S.F. D’Souza // Analytical Methods. — 2011. - Issue 3. - PP. 1981 - 1987.

8. Erel, O. A novel automated method to measure total antioxidant response against potent free radical reactions / O. Erel // Clinical Biochemistry. - 2004. - Vol. 37, Issue 2. — PP. 112 - 119.

9. Rapid electrochemical detection and identification of catalase positive micro-organisms / N. Sippy, R. Luxton, R.J. Lewis, D.C. Cowell // Biosensors and Bioelectronics. — 2003. — Vol. 18, Issues 5-6. PP. $741-749$.

10. Majumdar, T. Rapid Electrochemical Quantification of Food Borne Pathogen Staphylococcus Aureus Based on Hydrogen Peroxide Degradation by Catalase / T. Majumdar, R. Chakraborty, U. Raychaudhuri // Journal of The Electrochemical Society. — 2013. — Vol. 160, Issue 4. — G75 — G78.

11. Величко, А.К. Методы лабораторного определения общей перекись разрушающей активности ферментов растений / А.К. Величко, В.Б. Соловьев, М.Т. Генгин // Известия ПГПУ им. В.Г. Белинского. — 2009. — № 14(18). — С. $44-48$.

\section{References}

1. Nikolenko, S.I. (2002). Autochthonous microflora of drinking mineral water. In K.D. Babov, M.V. Loboda, E.A. Kolesnik, E.M. Nikipelova (Eds.), Low-mineralized sodium chloride mineral waters of Ukraine (pp. 59-68). Odessa: UNESCO.

2. Nikolenko, S.I., Slavina, N.G., Zaytseva, K.B. and Glukhovskaya, S.N. (2001). Therapeutically active metabolites of mineral waters microflora. Water and Health $-2001,159-162$.

3. Serikov, Yu.A. and Serkova, N.V. (2010). Titrimetric method for determination of chlorate-ion in natural waters. Industrial Laboratory, 76(10), 21-24.

4. Ashikhmina, T.Ya. (Ed.). (2005) Bioindication and biotesting as methods of environmental condition study. Kirov: Vyatka State Humanities University.

5. Naazeri, S., Rostamian, M., Yaghmaei, B. and Hedayati, M. (2014). Fluorimetry as a simple and sensitive method for determination of catalase activity. Zahedan Journal of Research in Medical Sciences, 16(2), 64-67.

6. Wu, M., Lin, Z. and Wolfbeis, O.S. (2003). Determination of the activity of catalase using a europium(III)-tetracycline-derived fluorescent substrate. Analytical Biochemistry, 320(1), 129-135.

7. Sandeep Kumar Jha and D'Souza, S.F. (2011). An ultra sensitive method for rapid in vitro catalase assay with software based approach using LabVIEW virtual instrumentation. Analytical Methods, 3, 1981-1987.

8. Erel, O. (2004). A novel automated method to measure total antioxidant response against potent free radical reactions. Clinical Biochemistry, 37(2), 112-119.

9. Sippy, N., Luxton, R., Lewis, R.J. and Cowell, D.C. (2003). Rapid electrochemical detection and identification of catalase positive micro-organisms. Biosensors and Bioelectronics, 18(5-6), 741-749. 
10. Majumdar, T., Chakraborty, R. and Raychaudhuri, U. (2013). Rapid electrochemical quantification of food borne pathogen Staphylococcus Aureus based on hydrogen peroxide degradation by catalase. Journal of The Electrochemical Society, 160(4), G75-G78.

11. Velichko, A.K., Solovev, V.B. and Gengin, M.T. (2009). Methods of laboratory definition of the common peroxide of destroying activity of enzymes of plants. Izvestia Penzenskogo gosudarstvennogo pedagogicheskogo universiteta imeni V.G. Belinskogo, 18, 44-48.

\section{AНОТАЦІЯ / АННОТАЦИЯ / ABSTRACT}

О.М. Нікіпелова, А.Ю. Кисилевська, Л.Б. Солодова. Розробка методу визначення каталазної активності мінеральної води. Біологічна дія мінеральних вод залежить не лише від хімічного складу, а й від продуктів метаболізму їх мікробних ценозів. Серед численних мікроорганізмів, які складають аутохтонну мікрофлору мінеральних вод, визначаються сапрофітні мікроорганізми - продуценти каталази, фізіологічна та біологічна роль якої є давно доведеною. Метою роботи є розробка методу визначення каталазної активності мінеральної води. Проаналізовано різні методи визначення каталазної активності в біологічних об'єктах. Розроблено спектрофотометричний метод визначення каталазної активності мінеральної води. Метод опрацьовано на ряді мінеральних вод України. Розраховано відносні стандартні відхилення, вони істотно нижче за норми похибки, які регламентуються для спектрофотометричного аналізу та діапазону цієї оптичної густини. Розроблений метод дозволяє з достатньою точністю та збіжністю проводити визначення каталазної активності мінеральних вод, ввести новий показник щодо оцінки їх якості і біологічної цінності.

Ключові слова: каталазна активність, мінеральні води, спектрофотометричний метод, сапрофітні мікроорганізми.

Е.М. Никипелова, А.Ю. Кисилевская, Л.Б. Солодова. Разработка метода определения каталазной активности минеральной воды. Биологическое действие минеральных вод зависит не только от химического состава, но и от продуктов метаболизма их микробных ценозов. Среди многочисленных микроорганизмов, составляющих аутохтонную микрофлору минеральных вод, определяются сапрофитные микроорганизмы - продуценты каталазы, физиологическая и биологическая роль которой является давно доказанной. Целью работы является разработка метода определения каталазной активности минеральной воды. Проанализированы различные методы определения каталазной активности в биологических объектах. Разработан спектрофотометрический метод определения каталазной активности минеральной воды. Метод отработан на ряде минеральных вод Украины. Рассчитаны относительные стандартные отклонения, они существенно ниже нормы погрешностей, которые регламентируются для спектрофотометрического анализа и диапазона этой оптической плотности. Разработанный метод позволяет с достаточной точностью и сходимостью проводить определение каталазной активности минеральных вод, ввести новый показатель оценки их качества и биологической ценности.

Ключевые слова: каталазная активность, минеральные воды, спектрофотометрический метод, сапрофитные микроорганизмы.

O.M. Nikipelova, A.Yu. Kisilevskaya, L.B. Solodova. Development of method for the mineral water catalase activity determination. Biological effects of mineral water depend not only on the chemical composition but also on the metabolic products of microbial cenosis. Among numerous microorganisms constituting the autochthonous microflora of mineral waters, we do evolve the saprophytic organisms producing the catalase, the saprophytes' physiological and biological role being proven a long ago. The research aim was to develop a method for determination of mineral water catalase activity. Analysed are various methods to determine the catalase activity in biological objects. Developed is a spectrophotometric method for determination of mineral water catalase activity. The method is efficiently tested with series of Ukrainian mineral waters. Calculated are the relative standard deviations which are significantly below normal errors, admitted at spectroscopic analysis and at the optic density range. The given method provides sufficient accuracy and convergence when estimating the mineral waters catalase activity, allowing to introduce a new index to assess the quality and biological value.

Keywords: catalase activity, mineral waters, spectrophotometric method, saprophytic microorganisms. 